\title{
Effects of different feeding regimens with protease supplementation on growth, amino acid digestibility, economic efficiency, blood biochemical parameters, and intestinal histology in broiler chickens
}

\author{
Shimaa A. Amer ${ }^{1 *}$, Rasha R. Beheiry², Doaa M. Abdel Fattah³, Elshimaa M. Roushdy ${ }^{4}$, Fardos A. M. Hassan ${ }^{4}$,
} Tamer Ahmed Ismail ${ }^{5}$, Noha M. A. Zaitoun ${ }^{6}$, Azza M. A. Abo-Elmaaty ${ }^{7}$ and Abdallah E. Metwally ${ }^{1}$

\begin{abstract}
Background: This study was conducted to estimate the impacts of using varied feeding regimens with or without protease supplementation on the growth performance, apparent amino acid ileal digestibility (AID\%), economic efficiency, intestinal histology, and blood biochemical parameters of broiler chickens. Three hundred one-day-old chicks (Ross 308 broiler) were randomly allotted to a $3 \times 2$ factorial design. The experimental design consisted of three feeding regimens; FR1: a recommended protein SBM diet, FR2: a low-protein SBM diet, and FR3: a low-protein diet with the inclusion of 5\% DDGS and 5\% SFM, with or without protease supplementation $(250 \mathrm{mg} / \mathrm{kg})$.

Results: Increased feed intake and feed conversion ratio were observed in the FR3 treatment during the starter stage and decreased body weight and body weight gain during the grower stage. However, there was no significant effect of the different feeding regimens, protease supplementation, or interaction on the overall performance. The economic value of diets also remained unaffected by the different feeding regimens, protease supplementation, or interaction. Protease supplementation resulted in lowering the AID\% of tryptophan and leucine. Reduced AID\% of methionine was evident in the FR2 + VE and FR3 - VE treatments. Histological findings substantiated the FR3 treatment mediated a decrease in the duodenal and jejunal villous height (VH), jejunal villous width (VW), and ileal WW, whereas, increase in the ileal crypt depth (CD). The FR2 + VE treatment reduced the VH:CD ratio in the duodenum. The duodenal CD and the jejunal goblet cell count were reduced as a consequence of protease supplementation. The FR3 + VE treatment documented a rise in duodenal $C D$, while an increase in the jejunal goblet cell count was observed in the FR3 - VE treatment. The FR3 treatment enhanced the IgM serum levels compared to the FR1 and FR2 treatments. IgM serum levels were also elevated following protease supplementation. FR3 + VE treatment increased IgM serum levels. The highest serum ALP was found in the FR3 treatment, whereas the lowest level was obtained in the FR2 treatment.
\end{abstract}

\footnotetext{
* Correspondence: shimaa.amer@zu.edu.eg

1 Department of Nutrition and Clinical Nutrition, Faculty of Veterinary

Medicine, Zagazig University, Zagazig 44511, Egypt

Full list of author information is available at the end of the article
}

\section{$\triangle B M C$}

(c) The Author(s). 2021 Open Access This article is licensed under a Creative Commons Attribution 4.0 International License, which permits use, sharing, adaptation, distribution and reproduction in any medium or format, as long as you give appropriate credit to the original author(s) and the source, provide a link to the Creative Commons licence, and indicate if changes were made. The images or other third party material in this article are included in the article's Creative Commons licence, unless indicated otherwise in a credit line to the material. If material is not included in the article's Creative Commons licence and your intended use is not permitted by statutory regulation or exceeds the permitted use, you will need to obtain permission directly from the copyright holder. To view a copy of this licence, visit http://creativecommons.org/licenses/by/4.0/ The Creative Commons Public Domain Dedication waiver (http://creativecommons.org/publicdomain/zero/1.0/) applies to the data made available in this article, unless otherwise stated in a credit line to the data. 
Conclusion: Low-protein SBM-based diets could be used without affecting the birds' growth. Altered morphometric measures of the intestine and increased IgM and ALP levels indicated the low-protein SBM/DDGSSFM diet-induced damage of the intestinal histoarchitecture and immune system of birds. These different diets and protease supplementation failed to affect economic efficiency positively.

Keywords: Broiler chicken, Protease, Dried distillers' grain with solubles, Sunflower meal, Growth performance, lleal digestibility, Gut health

\section{Background}

Dietary protein and amino acid balance exhibit a substantial role in gut health and performance [1]. Potential profits of low-protein diets include reducing the cost of feeding, nitrogen excretion, and environmental impact [2]. The higher utilization of nutrients by farm animals incurs a decrease in nutrient input and loss associated with the animal product and is thus beneficial. Hence, the impact of animal husbandry on the environment is reduced. Crude protein and phosphorus are environmentally related nutrients in poultry feed [3]. Cecal bacteria ferment around $10-43 \%$ of the undigested proteins [4]. Therefore, the birds' gut health can be alleviated by reducing dietary crude protein levels and their undigested contents in the ileum or cecum. The effects of low-protein diets fortified with amino acids on broiler chickens' growth and carcass features, estimated in several trials, reveal conflicting outcomes, leading to an ambiguous conclusion regarding the consequence of these diets on broilers' applied production. Some studies reported no significant effect of low-protein diets on growth performance [5-7]. However, broilers fed lowprotein diets (more than 3\%) documented a lower growth rate and inferior carcass composition even after satisfying all nutrient requirements [8-10]. Zulkifli et al. [11] claimed reduced growth performance of broilers fed on low-protein diets under heat stress. However, lowprotein diets were advantageous in enhancing survivability.

An increase in average daily gain, average daily feed intake, protein intake, energy intake, and eviscerated carcass weight was achieved by incorporating $110 \%$ Threonine in $97.5 \% \mathrm{CP}$ of Ross recommendations. Compared to the $100 \%$ CP diets, low dietary protein encouraged abdominal fat deposition, increased serum level of uric acid, total cholesterol, and alanine aminotransferase, and decreased triglycerides [12]. Attia et al. [2] demonstrated that supplementing low-protein with amino acids improved protein utilization in finishing broilers in comparison with the high-protein diet. Moreover, no negative effects on carcass yield and breast muscle composition were witnessed by feeding a low protein diet $(15 \% \mathrm{CP})$ and supplemented with lysine and methionine; however, there was a decrease in the nitrogen excretion by $21 \%$.
Feed enzyme supplementation can aggravate nutrient utilization by broilers outside of a possible base for the digestive system [13, 14]. The utilization of dietary proteins and amino acids may be enhanced by protease supplementation $[15,16]$. The nutritionists, therefore, preserve the growth and enhance poultry production sustainability by adding protease to low-protein diets [17]. Improved AA digestibility, feed conversion, and broiler chickens' intestinal integrity were achieved by protease supplementation [18]. Another study confirmed that supplementing proteases may alter available substrates for bacterial growth in the gut [19]. The effects of protease supplementation are also controversial. Reports suggested an increase $[18,20,21]$, decrease $[22,23]$, or no effect [24-26] on the AA digestibility by protease supplementation in broiler and turkey. Protease effect on the amino acid digestibility depends on its product [27] and supplementation level [20]. The feed ingredient composition directly influences the substrate and modulates other factors affecting the enzymes of the digestive system.

A massive increase in feed cost over the past decade encouraged the hunt for cost-effective feed ingredients [28]. Soybean meal has been extensively replaced by sunflower meal (SFM) as a substitute in poultry feeds [29]. Furthermore, new developments in de-hulling technology facilitated the production of a high-protein SFM, with higher crude protein (46\%) and fewer crude fiber (CF, 8 to 14\%) than partially de-hulled SFM (34 to $40 \%$ $\mathrm{CP}$ and 15 to $19 \% \mathrm{CF}$ ) and the standard (23 to $30 \% \mathrm{CP}$ and 22 to $28 \%$ CF) [30-33]. Distiller's dried grain with solubles (DDGS), an ethanol industry by-product, is obtained from cereal grain starch fermentation in ethanol plants. Corn, an excellent source of fermentable starch, is the primary grain used in ethanol fuel production. Corn DDGS is a rich source of amino acids, energy, minerals, water-soluble vitamins, linoleic acid, and xanthophylls for poultry feeds [34, 35]. Recent biofuel production trends have supplied nutritionists a chance to use DDGS as substitutes to protein supplements in poultry diets.

Therefore, the present study was designed to determine the effects of dietary supplementation of protease $(250 \mathrm{mg} / \mathrm{kg})$ to different feeding regimens (FR1: a recommended protein SBM diet, FR2: a low-protein SBM 
diet, and FR3: a low-protein diet with the inclusion of 5\% DDGS and 5\% SFM) on the growth performance parameters, amino acid ileal digestibility, economic efficiency, intestinal histomorphology, and blood biochemical parameters of broiler chickens.

\section{Results}

\section{Growth performance}

No significant interaction was observed between the different feeding regimens and protease on birds' growth all over the experimental period $(P>0.05)$. Regardless of the protease effect, increased feed intake and FCR $(P=$ $0.00)$ were documented by feeding birds on the FR3 treatment (low-protein SBM/DDGS-SFM diet) than FR1 and FR2 treatments during the starter period. Birds fed on the FR3 treatment revealed decreased BW and BWG compared to birds fed the FR1 treatment during the grower stage $(P<0.05)$. Different feeding regimes manifested no effect on the growth during the finisher period. The parameters all over the experimental period $(P>0.05)$ (Table 1$)$ substantiated that, regardless of the diet effect, protease supplementation had no improving effect on the growth. No mortalities were recorded all over the experimental period among the different treatments.

\section{Apparent ileal digestibility coefficient (AID\%) of amino acids}

A significant interaction between the different feeding regimens and protease level highlighted decreased AID\% of methionine in the FR2 + VE and FR3 - VE treatment groups compared to the FR1 - VE treatment group $(P=$ 0.006). The AID\% of tryptophan was the highest in the FR1 + VE and FR3 - VE treatment groups, while, lowest in the FR2 + VE treatment group $(P=0.02)$. The AID\% of lysine, threonine, arginine, leucine, isoleucine and valine were insignificantly varied among the different treatments $(P>0.05)$. Regardless of the protease effect, a decrease in the AID\% of methionine, arginine, leucine, isoleucine, and valine were noted in the FR2 and FR3 treatments compared to the FR1 treatment $(P<0.05)$. Regardless of diet effect, protease supplemented groups manifested lower AID\% of tryptophan and leucine than non-supplemented groups $(P<0.05)$ (Table 2$)$.

\section{Economic efficiency}

As summarized in Table 3, the economic efficiency indicators such as feed costs, total costs, total return, net profit, feed cost $/ \mathrm{kg}$ gain, economic efficiency, and performance index remained unaffected by the different feeding regimens, protease supplementation, or their interaction.

\section{Histological findings of the small intestine}

A standard histological structure formed from tunica mucosa, consisting of lamina epithelialis, lamina propria, and thin muscularis mucosa, was reflected in the light microscopic examination of the small intestine in the three segments for all treatments. The intestinal villi, the characteristic feature of the mucosa, differed in shape and size in each segment. The villi were nearly pointed in the duodenum, while comparatively shorter and broader in the jejunum. The villi were very short and absent in the ileum in other regions with blunt, apical, and broad basal parts. The lamina epithelialis were lined with simple columnar cells with goblet and enterochromaffin cells. The lamina propria formed from loose connective tissue contains intestinal glands or crypts, which were lined with simple columnar epithelium cells and goblet cells. The latter gave a positive reaction with PAS and alcian blue stains between the columnar lining of villi and crypts. The tunica submucosa formed from a thin layer of loose connective tissue with no Brunner's glands. The tunica musculosa arose from thick inner circular and thin outer longitudinal of smooth muscle fibers. The tunica serosa consisted of loose connective tissue, blood vessels and lined by mesothelial cells (Figs. $1,2$ and 3$)$.

\section{Morphometric measures of the small intestine}

The morphometric measurements of the different parts of the small intestine of birds fed on the different treatments were illustrated in Table 4 and Figs. 1, 2 and 3. A significant interaction between the different feeding regimens and protease supplementation revealed increased duodenal crypt depth in birds fed on the FR3 + VE treatment $(P=0.04)$ and increased jejunal goblet cell count in the birds fed on the FR3 - VE treatment $(P=0.02)$. There was a reduction in the $\mathrm{VH}: \mathrm{CD}$ ratio in the duodenum for the FR2 + VE treatment group $(P=0.03)$. Regardless of protease effect, birds fed on the FR3 treatment manifested decreased duodenal and jejunal villous height, jejunal VW, and ileal VW, whereas increased ileal CD $(P<0.05)$. For the FR2 treatment, a decreased $\mathrm{VH}: \mathrm{CD}$ ratio in the jejunum and duodenum was witnessed $(P=0.02, P=0.002$, respectively). Regardless of diet effect, protease supplementation increased duodenal $\mathrm{CD}$, decreased jejunal goblet cells, and decreased $\mathrm{VH}: \mathrm{CD}$ ratio in the jejunum $(P<0.05)$.

\section{Blood biochemical parameters}

The serum levels of total protein, albumin, globulin, albumin/globulin ratio, and complement 3 were not significantly affected by the different feeding regimens, protease supplementation, or their interaction $(P<0.05)$. Increased IgM serum levels resulted from a significant interaction between the FR3 diet and protease 


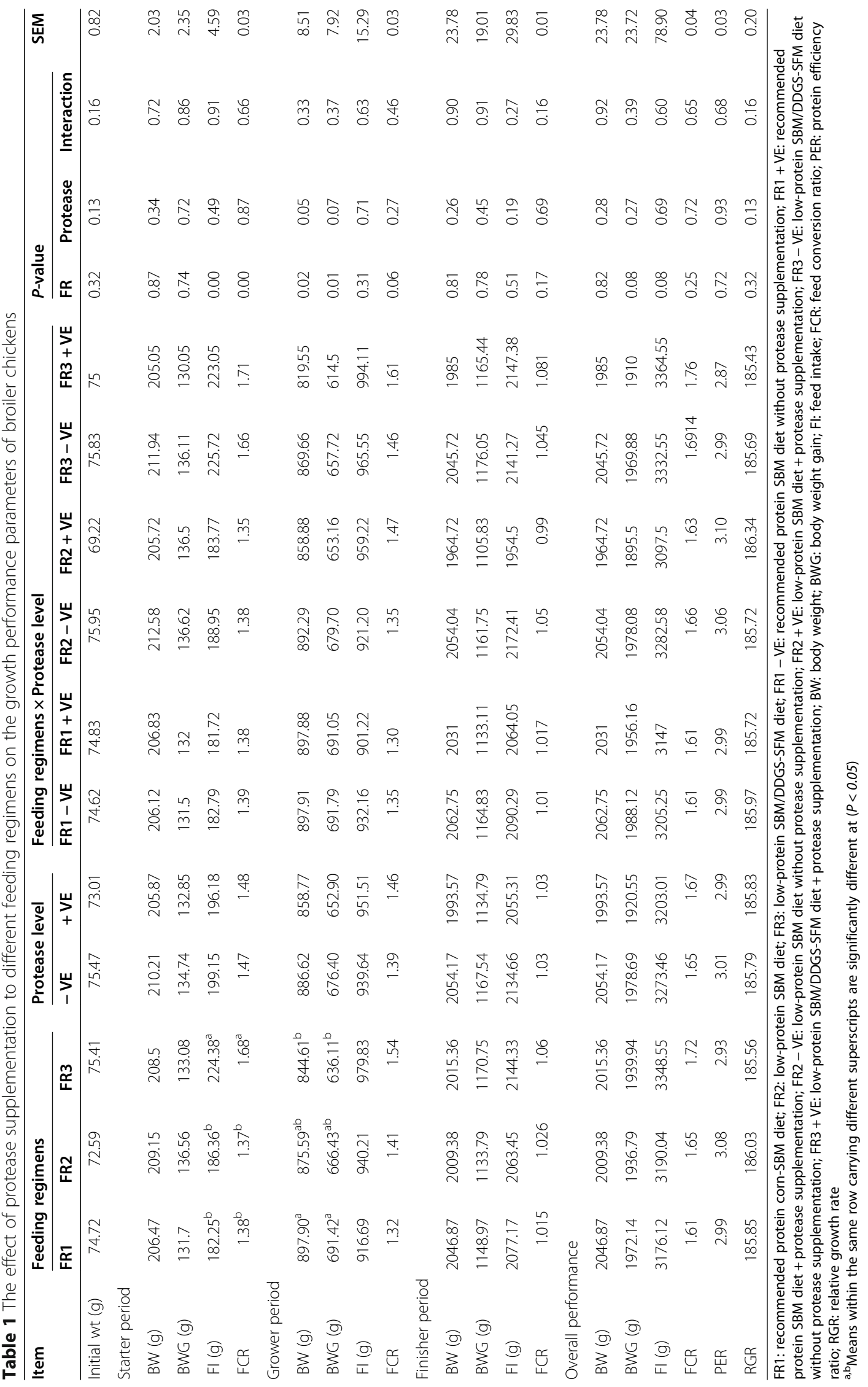


Table 2 The effect of different feeding regimens, protease supplementation, or their interaction on the blood biochemical parameters of broiler chickens

\begin{tabular}{|c|c|c|c|c|c|c|c|c|c|c|c|c|c|c|c|}
\hline \multirow[t]{2}{*}{ Item } & \multicolumn{3}{|c|}{ Feeding regimens } & \multicolumn{2}{|c|}{$\begin{array}{l}\text { Protease } \\
\text { level }\end{array}$} & \multicolumn{6}{|c|}{ Feeding regimens $\times$ Protease level } & \multicolumn{3}{|c|}{$P$-value } & \multirow[t]{2}{*}{ SEM } \\
\hline & FR1 & FR2 & FR3 & - VE & + VE & $\begin{array}{l}\text { FR1 - } \\
\text { VE }\end{array}$ & $\begin{array}{l}\text { FR1 + } \\
\text { VE }\end{array}$ & $\begin{array}{l}\text { FR2 - } \\
\text { VE }\end{array}$ & $\begin{array}{l}\text { FR2 + } \\
\text { VE }\end{array}$ & $\begin{array}{l}\text { FR3 - } \\
\text { VE }\end{array}$ & $\begin{array}{l}\text { FR3 + } \\
\text { VE }\end{array}$ & FR & Protease & Interaction & \\
\hline Methionine & $98.74^{\mathrm{a}}$ & $98.69^{b}$ & $98.69^{b}$ & 98.72 & 98.70 & $98.75^{a}$ & $98.73^{a b}$ & $98.72^{a b}$ & $98.66^{c}$ & $98.68^{b c}$ & $98.71^{a b c}$ & 0.006 & 0.06 & 0.01 & 0.007 \\
\hline Lysine & 99.14 & 98.85 & 98.92 & 99.07 & 98.87 & 99.39 & 98.89 & 98.91 & 98.78 & 98.90 & 98.94 & 0.40 & 0.29 & 0.45 & 0.015 \\
\hline Threonine & 98.43 & 98.47 & 98.47 & 98.46 & 98.45 & 98.44 & 98.41 & 98.51 & 98.44 & 98.44 & 98.50 & 0.20 & 0.64 & 0.15 & 0.008 \\
\hline Tryptophan & 98.76 & 98.70 & 98.69 & $98.74^{a}$ & $98.69^{b}$ & $98.73^{a b}$ & $98.78^{a}$ & $98.77^{a}$ & $98.64^{b}$ & $98.71^{a b}$ & $98.67^{\mathrm{ab}}$ & 0.06 & 0.04 & 0.02 & 0.015 \\
\hline Arginine & $98.75^{a}$ & $98.68^{b}$ & $98.66^{b}$ & 98.69 & 98.70 & 98.75 & 98.75 & 98.68 & 98.67 & 98.65 & 98.68 & 0.00 & 0.37 & 0.12 & 0.004 \\
\hline Isoleucine & $86.10^{a}$ & $85.68^{b}$ & $85.41^{b}$ & 85.70 & 85.76 & 86.04 & 86.16 & 85.81 & 85.56 & 85.25 & 85.56 & 0.002 & 0.48 & 0.08 & 0.05 \\
\hline Leucine & $90.89^{a}$ & $90^{b}$ & $89.94^{b}$ & $90.39^{a}$ & $90.16^{b}$ & 91.05 & 90.74 & 90.11 & 89.88 & 90 & 89.88 & 0.00 & 0.01 & 0.52 & 0.02 \\
\hline Valine & $98.55^{a}$ & $98.50^{b}$ & $98.46^{c}$ & 98.50 & 98.51 & 98.55 & 98.55 & 98.50 & 98.51 & 98.45 & 98.46 & 0.00 & 0.53 & 0.86 & 0.006 \\
\hline
\end{tabular}

FR1: recommended protein corn-SBM diet; FR2: low-protein SBM diet; FR3: low-protein SBM/DDGS-SFM diet; FR1 - VE: recommended protein SBM diet without protease supplementation; FR1 + VE: recommended protein SBM diet + protease supplementation; FR2 - VE: low-protein SBM diet without protease supplementation; FR2 + VE: low-protein SBM diet + protease supplementation; FR3 - VE: low-protein SBM/DDGS-SFM diet without protease supplementation; FR3 + VE: low-protein SBM/DDGS-SFM diet + protease supplementation

a,b,c Means within the same row carrying different superscripts are significantly different at $(P<0.05)$

supplementation (FR3 + VE) compared to other treatments $(P=0.04)$. Irrespective of the protease effect, marked elevation of IgM serum levels was observed in birds fed on the FR3 treatment compared to the FR1 and FR2 treatments $(P=0.01)$. The highest serum ALP was found in the FR3 treatment, and the lowest level was obtained in the FR2 treatment $(P=0.04)$. Regardless of the diet effect, protease supplementation increased IgM serum level $(P=0.04)$ (Table 5).

\section{Discussion}

Dietary protein plays a significant role in digestive system development and growth performance. Modern poultry primarily focuses on reducing the feed cost to optimize economic benefits since feed is the main factor determining the total production cost, and crude protein is one of the fundamental cost constituents of poultry feed [36]. The current study documented that birds fed on a low-protein SBM/DDGS-SFM diet exhibited increased feed intake and FCR during the starter period and decreased BW and BWG during the grower stage. Reduced digestibility of most amino acids, coupled with the damage in the intestinal histomorphology observed in birds fed with a low-protein SBM/DDGS-SFM diet, could justify the above findings. The insignificant effect of dietary protease on the growth performance during

Table 3 The effect of different feeding regimens, protease supplementation, or their interaction on the economic efficiency

\begin{tabular}{|c|c|c|c|c|c|c|c|c|c|c|c|c|c|c|c|}
\hline \multirow[t]{2}{*}{ Item } & \multicolumn{3}{|c|}{ Feeding regimens } & \multicolumn{2}{|c|}{$\begin{array}{l}\text { Protease } \\
\text { level }\end{array}$} & \multicolumn{6}{|c|}{ Feeding regimens $\times$ Protease level } & \multicolumn{3}{|c|}{$P$-value } & \multirow[t]{2}{*}{ SEM } \\
\hline & FR1 & FR2 & FR3 & $-\mathrm{VE}$ & $+\mathrm{VE}$ & $\begin{array}{l}\text { FR1 - } \\
\text { VE }\end{array}$ & $\begin{array}{l}\text { FR1 + } \\
\text { VE }\end{array}$ & $\begin{array}{l}\text { FR2 - } \\
\text { VE } \\
\end{array}$ & $\begin{array}{l}\text { FR2 }+ \\
\text { VE }\end{array}$ & $\begin{array}{l}\text { FR3 - } \\
\text { VE }\end{array}$ & $\begin{array}{l}\text { FR3 + } \\
\text { VE }\end{array}$ & $\mathrm{FR}$ & Protease & Interaction & \\
\hline $\begin{array}{l}\text { Total return } \\
\text { (USD)/bird }\end{array}$ & 2.98 & 2.93 & 2.94 & 2.99 & 2.91 & 3.01 & 2.96 & 2.99 & 2.86 & 2.98 & 2.89 & 0.81 & 0.26 & 0.90 & 0.03 \\
\hline Net profit (USD) & 1.23 & 1.20 & 1.18 & 1.24 & 1.17 & 1.24 & 1.22 & 1.23 & 1.17 & 1.23 & 1.13 & 0.85 & 0.37 & 0.89 & 0.03 \\
\hline Total costs (USD) & 1.75 & 1.72 & 1.75 & 1.75 & 1.73 & 1.76 & 1.74 & 1.75 & 1.68 & 1.74 & 1.76 & 0.49 & 0.28 & 0.40 & 0.01 \\
\hline Feed costs (USD) & 1.27 & 1.24 & 1.27 & 1.28 & 1.25 & 1.28 & 1.26 & 1.28 & 1.21 & 1.27 & 1.28 & 0.49 & 0.28 & 0.40 & 0.01 \\
\hline $\begin{array}{l}\text { Economic } \\
\text { efficiency }\end{array}$ & 0.96 & 0.97 & 0.92 & 0.96 & 0.94 & 0.96 & 0.96 & 0.96 & 0.97 & 0.97 & 0.88 & 0.78 & 0.59 & 0.73 & 0.02 \\
\hline $\begin{array}{l}\text { Feed cost/kg gain } \\
\text { (USD) }\end{array}$ & 0.64 & 0.64 & 0.65 & 0.64 & 0.65 & 0.64 & 0.64 & 0.64 & 0.64 & 0.64 & 0.67 & 0.75 & 0.69 & 0.63 & 0.01 \\
\hline $\begin{array}{l}\text { Performance } \\
\text { index\% }\end{array}$ & 127.29 & 122.35 & 111.15 & 124.38 & 116.14 & 128.11 & 126.46 & 124.10 & 120.59 & 120.92 & 101.37 & 0.15 & 0.21 & 0.48 & 3.26 \\
\hline
\end{tabular}

FR1: recommended protein corn-SBM diet; FR2: low-protein SBM diet; FR3: low-protein SBM/DDGS-SFM diet; FR1 - VE: recommended protein SBM diet without protease supplementation; FR1 + VE: recommended protein SBM diet + protease supplementation; FR2 - VE: low-protein SBM diet without protease supplementation; FR2 + VE: low-protein SBM diet + protease supplementation; FR3 - VE: low-protein SBM/DDGS-SFM diet without protease supplementation, FR3 + VE: low-protein SBM/DDGS-SFM diet + protease supplementation 


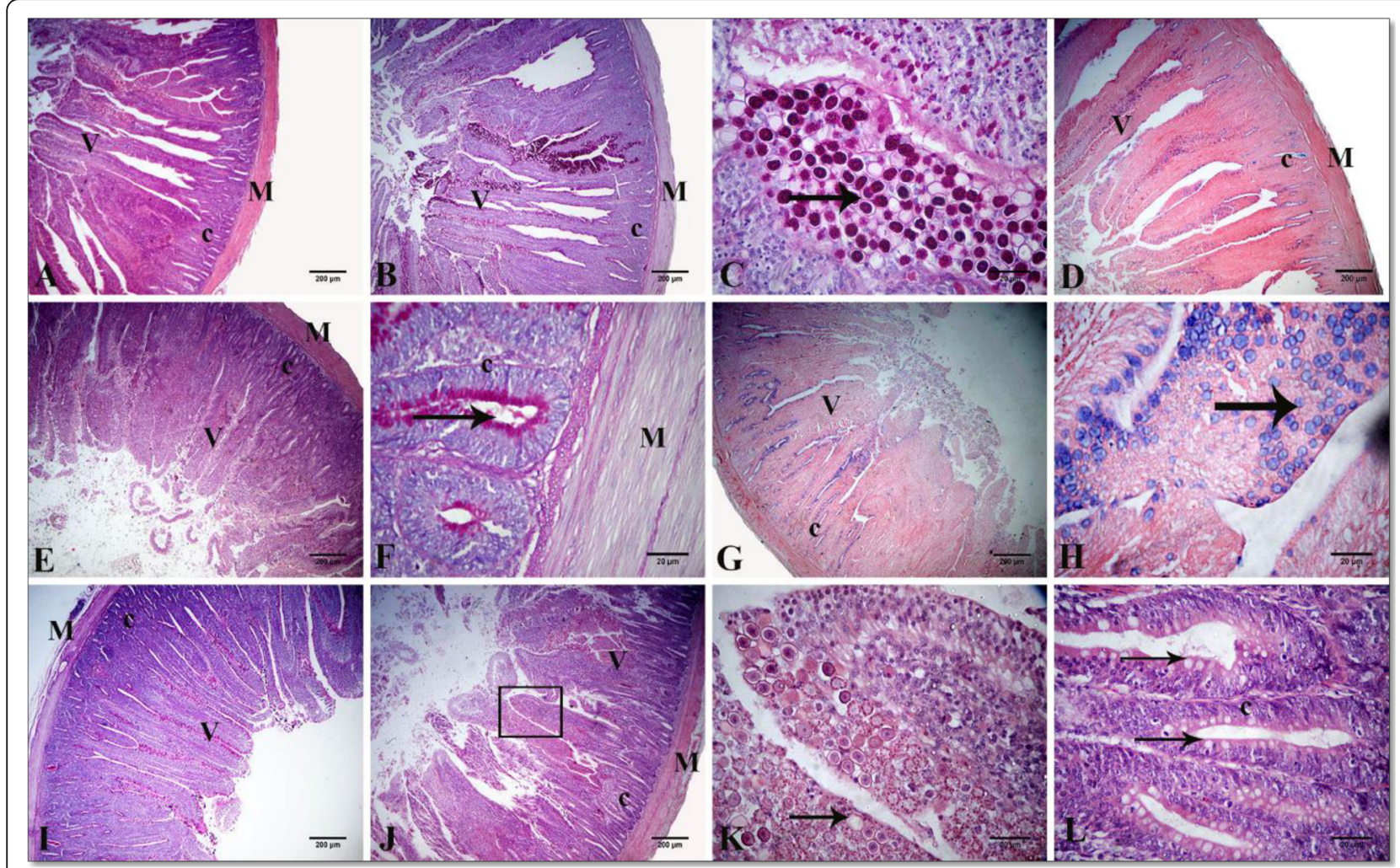

Fig. 1 A photomicrograph of chicken intestinal tissue sections highlighting normal histological structure in cross-section of the duodenum in group I $(\mathbf{A}-\mathbf{C})$, group II (D), group III (E, F), group IV $(\mathbf{G}, \mathbf{H})$, group V (I), and group VI $(\mathbf{J}, \mathbf{K}, \mathbf{L})$. Villus $(\mathbf{V})$, crypt (c), goblet cells (arrows), and tunica musculosa (M). Stain: H \& E in (A, E, J, K, L), alcian blue (D, G, H), and PAS in (B, C, F, I). I (FR1 - VE): recommended protein SBM diet without protease supplementation, II (FR1 + VE): recommended protein SBM diet + protease supplementation, III (FR2 - VE): low-protein SBM diet without protease supplementation, IV (FR2 + VE): low-protein SBM diet + protease supplementation, V (FR3 - VE): low-protein SBM/DDGS-SFM diet without protease supplementation, VI (FR3 + VE): low-protein SBM/DDGS-SFM diet + protease supplementation

the whole period may be attributed to the nonsignificant effect on the amino acid's digestibility observed in our study. Furthermore, protease supplementation to the different feeding regimens failed to impart any significant effect on broiler growth, which may be explained by the protease supplements' adverse effect on the endogenous enzyme secretion [25]. Another assumption for this result is the sufficiency of the amount of proteases present in the gut for protein digestion, or it might be related to the animal's adaptation [37]. However, the overall growth performance remained unaffected by the interaction between the different feeding regimens (FR1: a recommended protein SBM diet, FR2: a low-protein SBM diet, FR3: a low-protein SBM/ DDGS-SFM diet) and protease supplementation. Moreover, the present study also reported insignificant interaction between the feeding regimens and protease supplementation on the AID\% except for the AID\% of methionine that was decreased in the FR2 + VE and FR3 - VE treatments. The AID\% of tryptophan was found to be highest in the FR1 + VE and FR2 - VE treatments, whereas lowest in the FR2 + VE treatment. Protease supplementation also showed no significant effect on AID\% except for the AID\% of tryptophan and leucine that was found to be reduced. These findings were in accordance with Siegert et al. [3], who detected no significant interaction between the source of protein and protease supplementation for nitrogen accretion and growth performance, and the outcome of the growth performance was comparable for SBM and SBM/SFM treatments. Furthermore, there was no prominent influence on the average daily gain and daily feed intake. They also claimed that the interaction between the protein source and enzyme supplementation had no effect on the prececal digestibility of crude protein and amino acids except for cystine. Lourenco et al. [38] reported that birds fed a low protein diet exhibited lower BWG and poorer overall FCR, but these parameters remained unaffected by protease inclusion. It can thus be assumed that the effect of protease on amino acid digestibility depends on the diet composition since the feed components provide the substrate for the working of the 


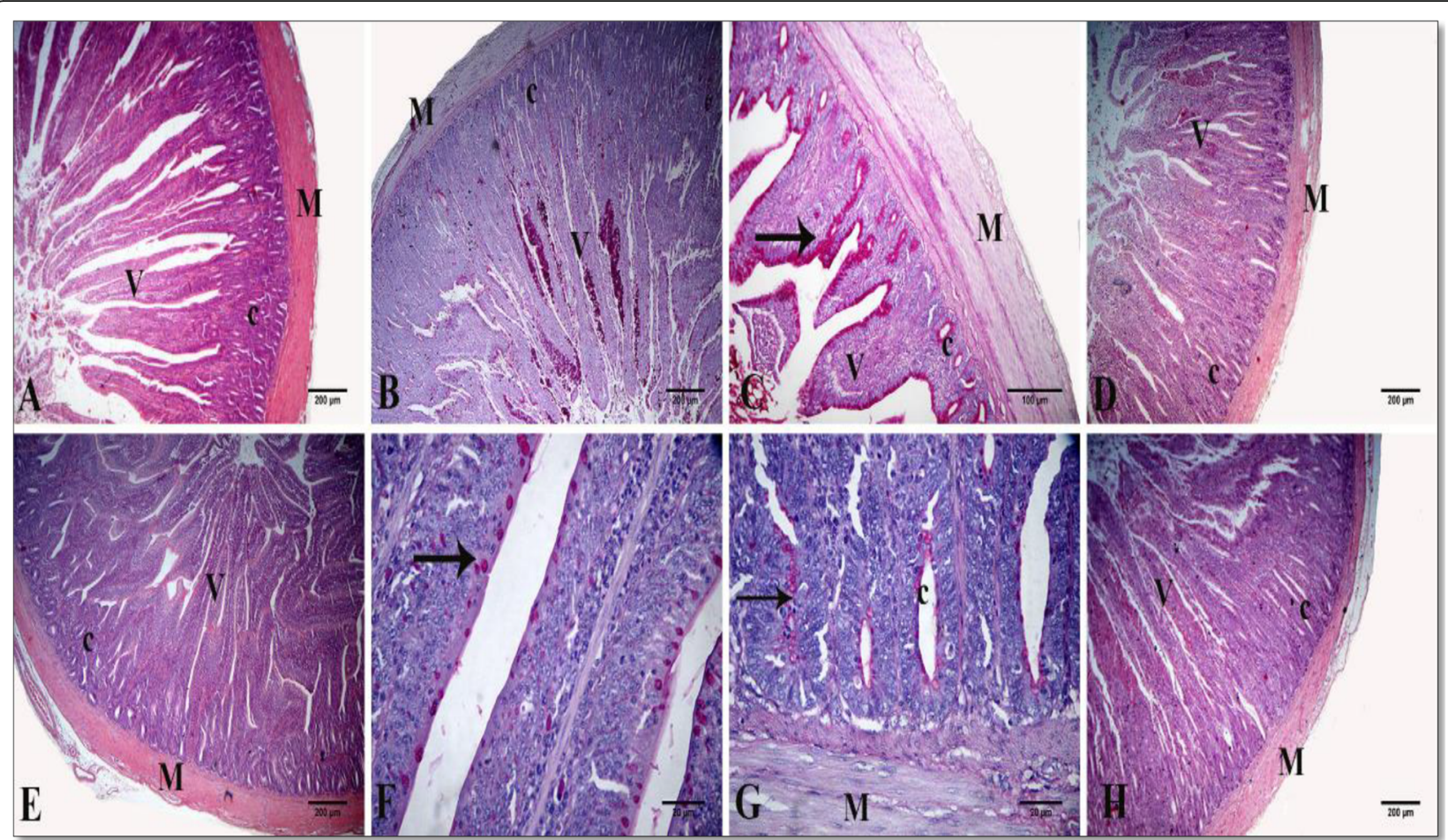

Fig. 2 A photomicrograph of chicken intestinal tissue sections showing the normal histological structure in cross-section of jejunum in group I $(\mathbf{A})$, group II (B), group III (C), group IV (D), group V (E-G), and group VI (H). Villus (V), crypt (c), goblet cells (arrows), and tunica musculosa (M). Stain: $\mathrm{H}$ \& E in $(\mathbf{A}, \mathbf{D}, \mathbf{E})$, and PAS in $(\mathbf{B}, \mathbf{C}, \mathbf{F}, \mathbf{G})$. I (FR1 - VE): recommended protein SBM diet without protease supplementation; II (FR1 + VE): recommended protein SBM diet + protease supplementation; III (FR2 - VE): low-protein SBM diet without protease supplementation; IV (FR2 + VE): low-protein SBM diet + protease supplementation; V (FR3 - VE): low-protein SBM/DDGS-SFM diet without protease supplementation; VI (FR3 + VE): low-protein SBM/DDGS-SFM diet + protease supplementation

enzymes. Toghyani et al. [39] observed that supplementing diets containing SBM or SBM/canola meal with protease failed to affect the crude protein's prececal digestibility. In agreement with these findings, Dalólio et al. [40] research also documented no effect on crude protein's prececal digestibility by supplementing the fullfat soybeans diets with protease. Moreover, Mahmood et al. [41] found that there was no effect on prececal digestibility of crude protein by supplementing protease to different levels of poultry by-product meal replacing the SBM. When fed wheat or sorghum-based diets, the protease effect on AID\% was influenced [42] and fed cornSBM diets [16]. Besides, the difference in the dosage and protease products used may be responsible for the effect of diet ingredients used and the differences in the results. Diets were supplemented with $500 \mathrm{mg} / \mathrm{kg}$ [42] or $200 \mathrm{mg} / \mathrm{kg}[16,39,40]$ of protease. An earlier study revealed that protease supplementation by $1600 \mathrm{mg} / \mathrm{kg}$ increased the ileal digestibility of AA, while there was no effect on supplementation with $200 \mathrm{mg} / \mathrm{kg}$ [22].

In contrast, the same protease product's potential was achieved after $200 \mathrm{mg} / \mathrm{kg}$ was complemented [20]. Low$\mathrm{CP}$ diets-induced reduced broilers' growth with constant ME:CP ratio was reported by Kamran et al. [43] though carcass traits were unaffected. Feeding a low-protein diet resulted in reduced nitrogen excretion that could, in turn, decrease the nitrogen loss to the environment $[8$, 44]. Law et al. [45] claimed that protease supplementation-mediated alleviation of the adverse effects of a low-protein diet on the broiler's growth leads to enhanced body weight gain, FCR, and carcass traits. Mahmood et al. [46] established improved body weight gain, FCR, nutrient digestibility, nitrogen retention with no effect on the feed intake in birds fed SBM diet with $3 \%$ poultry by-product meal and supplemented with protease compared to those fed on a conventional diet (corn-SBM diet without protease supplementation). Improved amino acid digestibility by protease supplements may justify the amelioration of growth in their study without effect on the feed intake [47]. Hussain et al. [48] found that supplementation of high-protein DDGSbased diets with protease and/or enzyme blend (mannanase and xylanase) exerted no significant effect on the broilers' growth and nutrient utilization. However, the high levels of corn-DDGS reduced growth performance [49-51]. Campasino et al. [52] informed that complementing the corn-DDGS based diets with NSPase (xylanase, glucanase, and galactosidase) exhibited no 


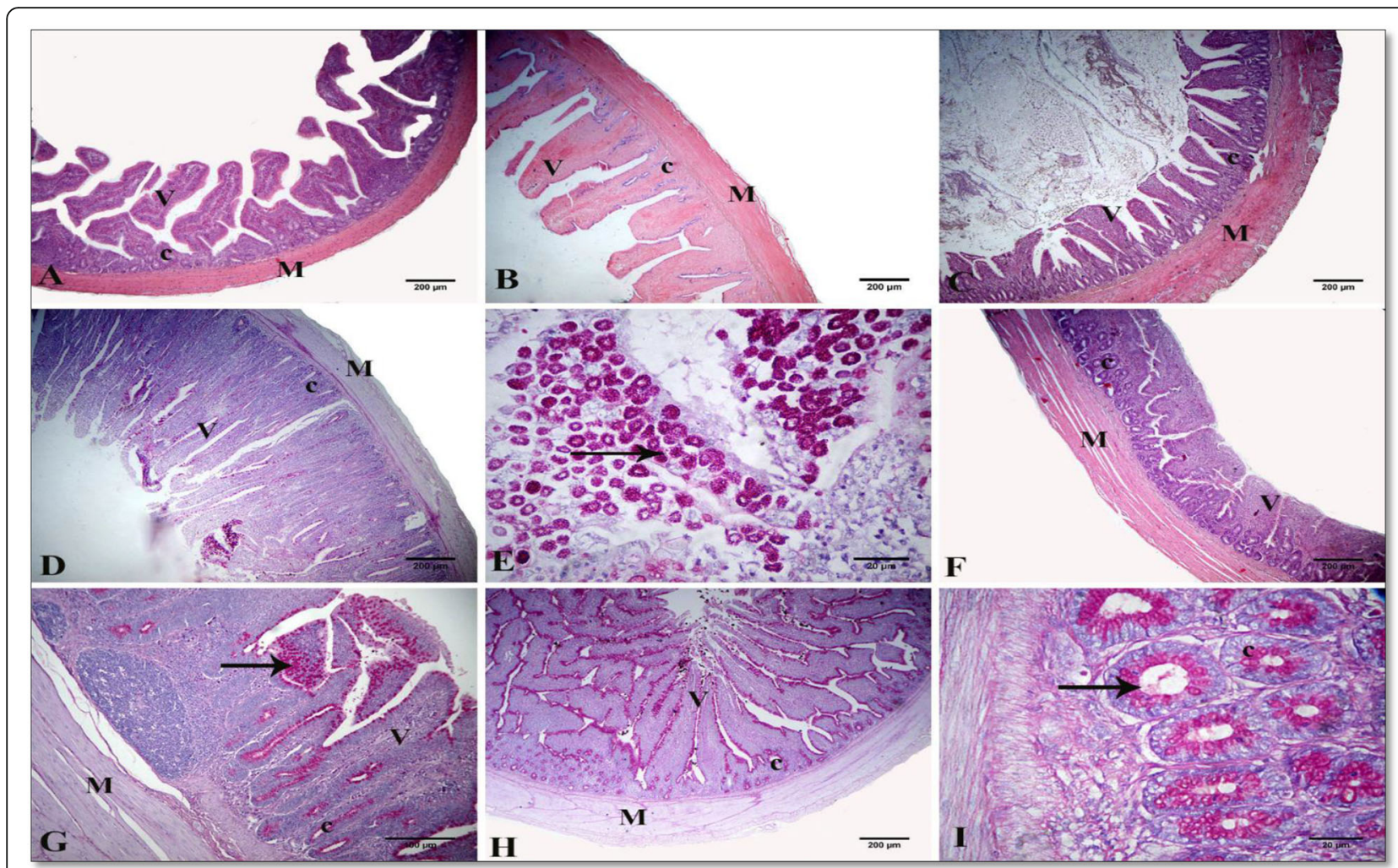

Fig. 3 A photomicrograph of chicken intestinal tissue sections showing the normal histological structure in cross-section of ileum in group I (A), group II (B), group III (C), group IV (D, E), group V (F, G), and group VI (H, I), Villus (V), crypt (c), goblet cells (arrows), and tunica musculosa (M). Stain: H \& E in (A, C, F), alcian blue (B), and PAS in (G-I). I (FR1 - VE): recommended protein SBM diet without protease supplementation; II (FR1 + VE): recommended protein SBM diet + protease supplementation; III (FR2 - VE): low-protein SBM diet without protease supplementation; IV (FR2 + VE): low-protein SBM diet + protease supplementation; V (FR3 - VE): low-protein SBM/DDGS-SFM diet without protease supplementation; VI (FR3 + VE): low-protein SBM/DDGS-SFM diet + protease supplementation

improving effect on the weight gain and FCR compared to the control diet. Protein digestibility was also found to remain unaffected by enzyme supplementation to $10 \%$ DDGS inclusion level, but the improvement was detected at 15\% DDGS addition. Protease supplementation alone or in combination with amylase and xylanase amended nitrogen digestibility, as obtained by Olukosi et al. [53]. Saleh et al. [54] documented that by improving the protein digestibility, protease supplementation (200-300 $\mathrm{mg} / \mathrm{kg}$ ) could alleviate growth performance. Barekatain et al. [55] indicated that body weight gain and feed intake could be maintained by protease supplementation to a high inclusion level of sorghum DDGS (20\%). Ndazigaruye et al. [56] validated increased BW and BWG and decreased FCR of broiler chickens by dietary protease during the starter period, while CP level has no effect on the BW and increased the FCR during the whole period. However, the interaction between $\mathrm{CP}$ and protease failed to significantly affect the growth performance. They concluded the relevance of dietary protease to young chicks, independent of CP levels.
Despite the similar performance of these different regimens to the control diet, there was no positive effect on the economic efficiency parameters, which may be explained by the fact that the reduced protein level was not so high to affect the diets' cost.

The efficacy of dietary protein utilization in poultry partially relies on the digestive traits [57]. The small intestine, particularly the absorptive epithelium's villi and crypts, plays a pivotal role in the last phase of the digestion and integration of nutrients [13, 58]. Intestinal growth can be evaluated by determining the $\mathrm{CD}, \mathrm{VH}$, and surface area, to estimate the area available for digestion and absorption $[57,59,60]$. Reports have been published on anatomical alterations in the intestine and changes in villi morphology in the different species depending on the diet type [61-63]. However, short reports highlight the correlation of the dietary nutrients' effects, particularly protein, with the poultry gastrointestinal tract development. The presence of digested nutrients in the small intestinal lumen mostly contributes to the morphological alterations in the intestinal villi in 


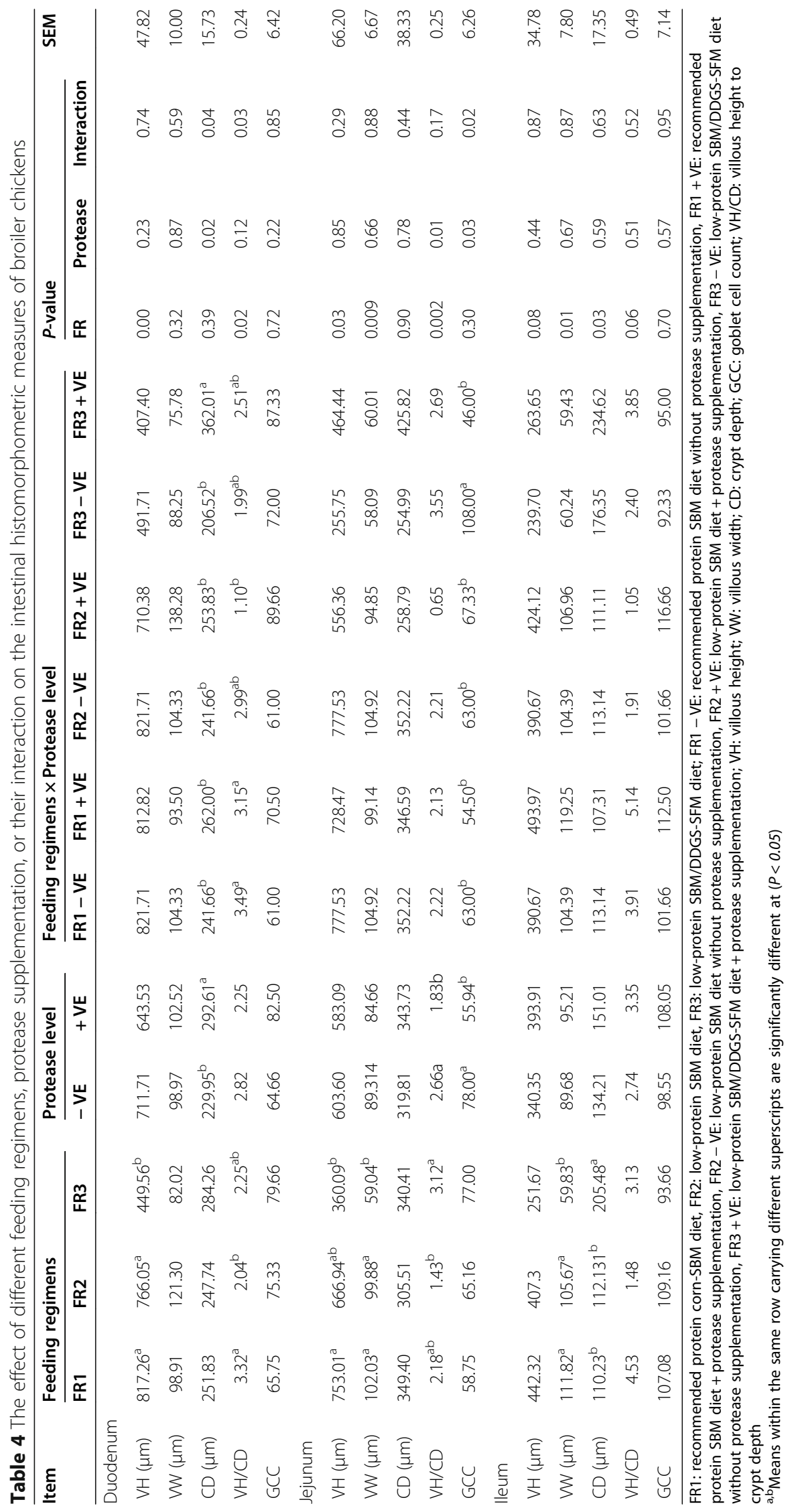


Table 5 The effect of protease supplementation in different feeding regimens on the blood biochemical parameters of broiler chickens

\begin{tabular}{|c|c|c|c|c|c|c|c|c|c|c|c|c|c|c|c|}
\hline \multirow[t]{2}{*}{ Item } & \multicolumn{3}{|c|}{ Feeding regimens } & \multicolumn{2}{|c|}{ Protease level } & \multicolumn{6}{|c|}{ Feeding regimens $\times$ Protease level } & \multicolumn{3}{|c|}{$P$-value } & \multirow[t]{2}{*}{ SEM } \\
\hline & FR1 & FR2 & FR3 & $-\mathrm{VE}$ & $+\mathrm{VE}$ & $\begin{array}{l}\text { FR1 - } \\
\text { VE }\end{array}$ & $\begin{array}{l}\text { FR1 + } \\
\text { VE }\end{array}$ & $\begin{array}{l}\text { FR2 - } \\
\text { VE }\end{array}$ & $\begin{array}{l}\text { FR2 + } \\
\text { VE }\end{array}$ & $\begin{array}{l}\text { FR3 - } \\
\text { VE }\end{array}$ & $\begin{array}{l}\text { FR3 + } \\
\text { VE }\end{array}$ & FR & Protease & Interaction & \\
\hline $\mathrm{TP}(\mathrm{g} / \mathrm{dL})$ & 7.98 & 7.517 & 8.40 & 7.47 & 8.46 & 7.72 & 8.24 & 7.40 & 7.63 & 7.29 & 9.51 & 0.59 & 0.17 & 0.48 & 0.33 \\
\hline $\begin{array}{l}\text { Albumin } \\
(\mathrm{g} / \mathrm{dL})\end{array}$ & 4.08 & 4.20 & 4.35 & 4.23 & 4.18 & 4.1 & 4.06 & 4.11 & 4.29 & 4.50 & 4.20 & 0.08 & 0.55 & 0.13 & 0.05 \\
\hline $\begin{array}{l}\text { Globulin } \\
\text { (g/dL) }\end{array}$ & 3.69 & 3.31 & 4.05 & 3.17 & 4.19 & 3.44 & 3.94 & 3.28 & 3.34 & 2.79 & 5.30 & 0.65 & 0.13 & 0.29 & 0.32 \\
\hline $\begin{array}{l}\mathrm{A} / \mathrm{G} \text { ratio } \\
(\%)\end{array}$ & 1.25 & 1.28 & 1.39 & 1.49 & 1.12 & 1.38 & 1.123 & 1.29 & 1.28 & 1.82 & 0.96 & 0.87 & 0.11 & 0.32 & 0.11 \\
\hline ALP(U/L) & $60.22 a b$ & $48.48 b$ & $74.23 a$ & 59.59 & 62.36 & 57.49 & 62.96 & 50.23 & 46.73 & 71.07 & 77.39 & 0.04 & 0.71 & 0.83 & 4.01 \\
\hline C3 (mg/dL) & 109.16 & 99.98 & 117.63 & 101.17 & 116.68 & 110 & 108.33 & 86.51 & 113.46 & 107 & 128.27 & 0.27 & 0.08 & 0.35 & 4.60 \\
\hline $\begin{array}{l}\text { lgM (mg/ } \\
\mathrm{dL} \text { ) }\end{array}$ & $94.73^{b}$ & $74.36^{\mathrm{b}}$ & $142.56^{\mathrm{a}}$ & $87.80^{b}$ & $119.97^{\mathrm{a}}$ & $94.77^{b}$ & $94.69^{b}$ & $73.04^{b}$ & $75.69^{b}$ & $95.59^{b}$ & $189.52^{\mathrm{a}}$ & 0.01 & 0.04 & 0.04 & 10.78 \\
\hline
\end{tabular}

FR1: recommended protein corn-SBM diet; FR2: low-protein SBM diet; FR3: low-protein SBM/DDGS-SFM diet; FR1 - VE: recommended protein SBM diet without protease supplementation, FR1 + VE: recommended protein SBM diet + protease supplementation, FR2 - VE: low-protein SBM diet without protease supplementation, FR2 + VE: low-protein SBM diet + protease supplementation, FR3 - VE: low-protein SBM/DDGS-SFM diet without protease supplementation, FR3 + VE: low-protein SBM/DDGS-SFM diet + protease supplementation; TP: total protein; A/G ratio: albumin/globulin ratio; ALP: alkaline phosphatase; C3: complement 3

${ }^{\mathrm{a}, \mathrm{b}}$ Means within the same row carrying different superscripts are significantly different at $(P<0.05)$

broilers [64]. The present study confirmed the lowprotein SBM/DDGS-SFM diet-induced alteration of the intestine's morphometric measures (decreased duodenal and jejunal villous height, jejunal VW, and ileal VW, and increased ileal $\mathrm{CD}$ ) that substantiate the reduced growth performance of birds fed on this diet during the starter and grower period and the reduced digestibility of most amino acids. The deleterious effect of low-protein diets on the intestinal morphometric measurements may be vindicated by lower concentrations of nonessential amino acids such as proline, glutamine, and glycine, effectively maintaining the epithelial layer consider a significant portion of the intestinal builders and gastrointestinal secretions [65].

Laudadio et al. [66] reported improved intestinal morphometric measures induced by a medium-protein diet (20.5\% CP), resulting in enhanced broiler chicken growth performance. The absence of any significant effect on the intestinal integrity of broiler chickens was documented by Hussain et al. [48] on supplementing high-protein-based diets by protease or enzyme blend (mannanase and xylanase). The study of Buwjoom et al. [67] assessed the effect of the use of long-standing feeding of low-protein diets in broiler chickens on the intestinal villi's histological features epithelial cells. They observed histological changes represented by long villi, large cell areas, and numerous mitotic cells in nutritional deficiency conditions, not only in hyper-nutrition conditions, which proposes that hypotrophied histological changes could indicate that the diet is nutritionally unbalanced. Barekatain et al. [68] also revealed no significant effect of dietary protein and AA levels on the $\mathrm{VH}, \mathrm{VW}$, crypt depth, and $\mathrm{VH}: \mathrm{CD}$ ratio in the jejunum and ileum, although a small surface area of the jejunal villi was observed on the birds fed with a low-protein diet than those on a standard-protein diet. In accordance with these findings, no significant interaction between crude protein level and protease on the $\mathrm{VH}, \mathrm{VW}, \mathrm{CD}$, $\mathrm{VH}: \mathrm{CD}$ ratio, and intestinal absorptive surface area in the duodenum, jejunum, and ileum were highlighted by Law et al. [45]. In contrast, protease supplementation depicted an increase in the intestinal absorptive surface area. Moghaddam et al. [69] recorded reduced VH and enhanced $C D$ in the duodenum and jejunum with increasing SFM levels.

The serum levels of TP, ALB, GL, ALB/GL ratio, and complement 3 were found to remain unaffected by the different feeding regimens, protease supplementation, or their interaction as reflected in the present study. Nonetheless, IgM serum level manifested a significant interaction in the FR3 + VE treatment group. The FR3 treatment group witnessed the highest serum ALP, while the minimal level was found in the FR2 treatment. Altered intestinal morphometric measures associated with increased serum ALP and IgM levels in birds fed the FR3 may indicate intestinal inflammation. Law et al. [45] recorded a significant interaction between crude protein level and protease on the serum levels of albumin but not for serum total protein. However, decreased serum ALB and TP were reported in broilers fed a low-protein diet. They also reported that protease supplementation failed to affect serum. TP. Saleh et al. [54] reported that 
protease supplementation (200-300 $\mathrm{mg} / \mathrm{kg}$ ) held no significant effect on serum TP. Furthermore, Perez [70] also observed that dietary inclusion of DDGS or cellulose accelerated recovery of young pigs challenged with pathogenic Escherichia coli. Nevertheless, this protective effect of DDGS was not detected in broilers challenged with E. acervuline [71]. Dietary inclusion of DDGS was found to lessen the intensity of intestinal lesions caused by Lawsonia intracellularis infection in young pigs, as noted by Whitney et al. [72]. Weber et al. [73] established that the expression of proinflammatory and antiinflammatory cytokines in the intestine was up-regulated in weanling pigs fed a diet with a 7.5\% DDGS inclusion level.

\section{Conclusion}

Low-protein SBM-based diets (1\% CP less than recommended by the Breeder's Guide) could be employed without negatively impacting the birds' growth. Owing to decreased amino acid digestibility, low-protein SMB/DDGS-SFM based diets reduced the growth performance during the starter and grower periods without influencing the overall growth performance. Altered morphometric measures of the intestine and increased IgM and ALP levels substantiated that low-protein SBM/DDGSSFM diet may impair the intestinal histoarchitecture and immune system of birds. Protease supplementation demonstrated no constructive effect on the growth performance parameters or amino acid digestibility. There was no positive effect of these different diets and protease supplementation on economic efficiency.

\section{Methods}

\section{Birds, experimental design, and diets}

Three hundred one-day-old chicks (Ross 308 broiler) were obtained from a commercial chick producer (Dakahlia Poultry, Mansoura, Egypt). Before the experiments, the chicks were acclimatized to a 3-day adaptation period to reach an average body weight of $74.35 \mathrm{~g} \pm 0.82$ (mean $\pm \mathrm{SE}$ ). The Ethical approval of the experimental protocol was obtained from the Institutional Animal Care and Use Committee of Zagazig University, Egypt (ZUIACUC-2020). All animal experiments were performed based on the recommendations described in "The Guide for the Care and Use of Laboratory Animals in scientific investigations". All the animal experiments also followed the ARRIVE guidelines. The trial continued for 35 days, with continuous lighting and adequate ventilation. Freshwater and feed were provided for ad libitum consumption throughout the investigation period. The chicks were reared in the same administrative, health, and environmental conditions throughout the experimental period. The routine health and vaccination practices were implemented strictly according to the recommendations. The chicks were examined daily for any health problems. After the study ended, all remaining chickens were freed.

\section{Experimental design and diets}

Birds were randomly allotted to a $3 \times 2$ factorial design (5 replicates/treatment, ten chicks/replicate). The experimental design consisted of three feeding regimens; FR1: a recommended protein SBM diet, FR2: a low-protein corn-SBM diet (1\% lower than recommended), and FR3: low-protein diet with the inclusion of DDGS and SFM (1\% lower than recommended) with or without protease supplementation $(250 \mathrm{mg} /$ kg) (Protease, Cibenza EP150, Novus Europe S.A./ N.V. Woluwe Atrium, Neerveld 101-103, 1200 Brussels, Belgium). The safety of Cibenza EP150 for broiler chicken has been verified [74]. Table 6 details the formulation and chemical composition of the basal diet. Following the Ross 308 broiler nutrition specifications' standard procedures, the proximate chemical analysis of the used feedstuffs and the experimental diets was conducted [75].

\section{Growth performance}

The average initial body weight was recorded on the 4th day of age, and then the body weight was recorded at 10 , 23, 35 days.

The body weight gain $(\mathrm{g} / \mathrm{bird})=\mathrm{W} 2-\mathrm{W} 1$, where W2 is the final body weight at the intended period, and W1 is the initial body weight in the same period.

Feedintake $(\mathrm{g} /$ bird $)=$ feedofferedweight - residuesleft/birds No.

The feed conversion ratio was estimated weekly: FCR = the amount of feed consumed (g)/Bodyweight gain (g).

The relative growth rate (RGR) was calculated using the equation described by [76].

$$
\mathrm{RGR}=\mathrm{W} 2-\mathrm{W} 1 / 1 / 2(\mathrm{~W} 1+\mathrm{W} 2) \times 100 .
$$

W1: the initial live weight (g), W2: the live weight at the end of the considered period (g).

Protein efficiency ratio (PER) was determined according to [77].

$$
\text { PER }=\text { Liveweightgain }(\mathrm{g}) / \text { Proteinintake }(\mathrm{g}) .
$$

\section{Amino acids ileal digestibility}

The amino acids' ileal digestibility was determined by estimating Titanium dioxide, an indigestible indicator substance, as described by Amer et al. [13]. The amino acid concentration in the diet and ileal digesta samples were 
Table 6 The proximate chemical composition of the experimental diets (\%)

\begin{tabular}{|c|c|c|c|c|c|c|c|c|c|c|}
\hline \multirow[t]{2}{*}{ Ingredients } & \multirow[t]{2}{*}{ Unit } & \multicolumn{3}{|c|}{ Starter stage (4-10 day) } & \multicolumn{3}{|c|}{ Grower stage (11-23 day) } & \multicolumn{3}{|c|}{ Finisher stage (24-35 day) } \\
\hline & & $\mathrm{T} 1-\mathrm{T} 2$ & T3-T4 & T5-T6 & $\mathrm{T1-T2}$ & T3-T4 & T5-T6 & $\mathrm{T1} 1-\mathrm{T} 2$ & T3-T4 & T5-T6 \\
\hline Corn $7.25 \%$ CP & $\%$ & 54 & 56.5 & 52.2 & 58 & 59.60 & 55.30 & 62.52 & 64 & 59.50 \\
\hline Soybean meal 47\% CP & $\%$ & 39 & 37.9 & 31.6 & 32 & 33.80 & 27.50 & 26.00 & 27 & 21 \\
\hline Corn gluten meal 60\% CP & $\%$ & 1.2 & - & - & 3.20 & - & - & 4.50 & 2.24 & 2 \\
\hline Corn DDGS 26.5\% CP & $\%$ & - & - & 5 & - & - & 5 & - & - & 5 \\
\hline Sunflower meal 36\% CP & $\%$ & - & - & 5 & - & - & 5 & - & - & 5 \\
\hline Oil (Soya) & $\%$ & 2 & 1.55 & 2.20 & 3 & 2.90 & 3.5 & 3.50 & 3.30 & 4 \\
\hline Dicalcium phosphate $18 \%$ & $\%$ & 2 & 2 & 1.80 & 1.70 & 1.70 & 1.55 & 1.45 & 1.45 & 1.33 \\
\hline Calcium carbonate & $\%$ & 0.5 & 0.40 & 0.40 & 0.50 & 0.45 & 0.50 & 0.50 & 0.45 & 0.50 \\
\hline DI methionine 99\% & $\%$ & 0.39 & 0.35 & 0.33 & 0.28 & 0.31 & 0.29 & 0.27 & 0.30 & 0.28 \\
\hline Sodium bicarbonate & $\%$ & 0.32 & 0.37 & 0.31 & 0.33 & 0.32 & 0.31 & 0.32 & 0.30 & 0.30 \\
\hline Broiler Premix ${ }^{a}$ & $\%$ & 0.3 & 0.30 & 0.40 & 0.30 & 0.30 & 0.30 & 0.30 & 0.30 & 0.30 \\
\hline L-LYSINE HCl 98\% & $\%$ & 0.25 & 0.29 & 0.32 & 0.30 & 0.25 & 0.37 & 0.28 & 0.27 & 0.38 \\
\hline Salt & $\%$ & 0.11 & 0.08 & 0.07 & 0.11 & 0.12 & 0.08 & 0.13 & 0.13 & 0.10 \\
\hline L-Threonine 98.5\% & $\%$ & 0.10 & 0.09 & 0.13 & 0.10 & 0.07 & 0.09 & 0.06 & 0.08 & 0.10 \\
\hline Choline & $\%$ & 0.06 & 0.07 & 0.10 & 0.07 & 0.07 & 0.10 & 0.07 & 0.07 & 0.10 \\
\hline Antimycotoxin & $\%$ & 0.1 & 0.1 & 0.10 & 0.10 & 0.10 & 0.10 & 0.10 & 0.10 & 0.10 \\
\hline Phytase enzyme & $\%$ & 0.005 & 0.005 & 0.005 & 0.005 & 0.005 & 0.005 & 0.005 & 0.005 & 0.005 \\
\hline \multicolumn{11}{|l|}{ Chemical analysis } \\
\hline Moisture & $\%$ & 11.35 & 11.44 & 11.19 & 11.23 & 11.32 & 11.07 & 11.18 & 11.25 & 11.00 \\
\hline Crude protein & $\%$ & 23.2 & 22.20 & 22.22 & 21.55 & 20.53 & 20.56 & 20.15 & 19.10 & 19.10 \\
\hline Crude fat & $\%$ & 4.91 & 4.49 & 5.53 & 6.04 & 5.87 & 6.85 & 6.67 & 6.43 & 7.50 \\
\hline Lysine & $\mathrm{g} / \mathrm{kg}$ & 14.48 & 13.71 & 13.77 & 13.20 & 13.05 & 13.05 & 11.55 & 11.57 & 11.55 \\
\hline Methionine & $\mathrm{g} / \mathrm{kg}$ & 7.34 & 6.76 & 6.73 & 6.18 & 6.14 & 6.12 & 5.97 & 6.02 & 5.97 \\
\hline Methionine + cystine & $\mathrm{g} / \mathrm{kg}$ & 10.88 & 10.37 & 10.22 & 9.58 & 9.34 & 9.40 & 9.19 & 9.08 & 9.12 \\
\hline Threonine & $\mathrm{g} / \mathrm{kg}$ & 9.85 & 9.41 & 9.62 & 9.13 & 8.52 & 8.55 & 8.03 & 7.96 & 7.99 \\
\hline Tryptophan & $\mathrm{g} / \mathrm{kg}$ & 2.83 & 2.75 & 2.63 & 2.49 & 2.50 & 2.38 & 2.18 & 2.17 & 2.07 \\
\hline Arginine & $\mathrm{g} / \mathrm{kg}$ & 15.53 & 15.09 & 14.79 & 13.72 & 13.76 & 13.49 & 12.07 & 12.02 & 11.80 \\
\hline Valine & $\mathrm{g} / \mathrm{kg}$ & 11.10 & 11.04 & 11.08 & 10.27 & 10.14 & 10.23 & 9.45 & 9.07 & 9.01 \\
\hline Calcium & $\mathrm{g} / \mathrm{kg}$ & 8.79 & 8.43 & 8.43 & 7.83 & 7.70 & 7.68 & 7.09 & 6.95 & 7 \\
\hline Av. Phosphorus & $\mathrm{g} / \mathrm{kg}$ & 4.98 & 4.98 & 4.91 & 4.47 & 4.49 & 4.49 & 4.03 & 4.04 & 4.09 \\
\hline Sodium & $\mathrm{g} / \mathrm{kg}$ & 1.59 & 1.59 & 1.59 & 1.62 & 1.61 & 1.61 & 1.67 & 1.60 & 1.67 \\
\hline Potassium & $\mathrm{g} / \mathrm{kg}$ & 9.19 & 9.11 & 8.87 & 8.05 & 8.41 & 8.19 & 7.07 & 7.29 & 7.11 \\
\hline $\mathrm{Cl}$ & $\mathrm{g} / \mathrm{kg}$ & 2.28 & 1.98 & 2.25 & 2.32 & 2.30 & 2.36 & 2.34 & 2.33 & 2.43 \\
\hline Crude fiber & $\%$ & 3.52 & 3.52 & 4.29 & 3.23 & 3.34 & 4.11 & 2.99 & 3.05 & 3.84 \\
\hline ME (kcal/kg) & $\mathrm{Kcal} / \mathrm{kg}$ & 2991.12 & 2969.7 & 2973.74 & 3103.42 & 3071.17 & 3070.72 & 3200.15 & 3173.76 & 3173.84 \\
\hline
\end{tabular}

T1 (FR1 - VE): recommended protein SBM diet without protease supplementation; T2 (FR1 + VE): recommended protein SBM diet + protease supplementation; T3 (FR2 - VE): low-protein SBM diet without protease supplementation; T4 (FR2 + VE): low-protein SBM diet + protease supplementation; T5 (FR3 - VE): low-protein SBM/DDGS-SFM diet without protease supplementation; T6 (FR3 + VE): low-protein SBM/DDGS-SFM diet + protease supplementation

aPremix per kg of diet: vitamin A, $1500 \mathrm{IU}$; vitamin D3, $200 \mathrm{IU}$; vitamin E, $10 \mathrm{mg}$; vitamin K3, $0.5 \mathrm{mg}$; thiamine, $1.8 \mathrm{mg}$; riboflavin, $3.6 \mathrm{mg}$; pantothenic acid, $10 \mathrm{mg}$; folicacid, $0.55 \mathrm{mg}$; pyridoxine, $3.5 \mathrm{mg}$; niacin, $35 \mathrm{mg}$; cobalamin, $0.01 \mathrm{mg}$; biotin, $0.15 \mathrm{mg}$; Fe, $80 \mathrm{mg}$; Cu, $8 \mathrm{mg} ; \mathrm{Mn}, 60 \mathrm{mg} ; \mathrm{Zn}, 40 \mathrm{mg}$; l, $0.35 \mathrm{mg}$; Se, $0.15 \mathrm{mg}$

evaluated according to $\mathrm{Li}$ et al. [78] and Siriwan et al. [79]. Tryptophan was ascertained separately, according to Ravindran and Bryden [80]. Titanium dioxide was estimated following the procedures delineated by Fenton and Fenton [81].
$\operatorname{AID}(\%)=100-[($ Ti $($ diet $) \times \mathrm{AA}($ ileum $)) /(\mathrm{TI}($ ileum $) \times \mathrm{AA}($ diet $)) \times 100]$

$\mathrm{Ti}$ (diet): titanium dioxide concentration in the diet. $\mathrm{Ti}$ (ileum): titanium dioxide concentration in ileal digesta. AA (ileum): the concentration of the test AA in ileal 
digesta. AA (diet): the concentration of the test AA in the diet.

\section{Economic efficiency}

Collective efficiency measures, which include total return, total costs, variable costs, and net profit, were calculated according to $[82,83]$.

Total feed cost (USD/bird) $=$ Total feed intake/ bird $\times$ Price of $1 \mathrm{~kg}$ feed.

Total cost (USD/bird) was computed by considering feed cost as well as the expenses of 1-day-old chick, litter, labor, veterinary services, electricity, and other miscellaneous expenditure, that were common to all groups.

Total return (USD/bird) = Live body weight/ bird $\times$ Price of kg body weight.

Net profit $(U S D /$ bird $)=$ Total returns - Total costs.

Economic efficiency (E.EF) $=$ Net profit $/$ Total feed cost.

Feed cost $/$ kg gain $($ USD $/$ bird $)=$ Total feed cost $/$ Total weight gain.

The performance index (PI) was calculated based on a previous study [84].

Performance index \% (PI) = final live body weight $(\mathrm{kg}) /$ feed conversion $\times 100$.

\section{Sample collection and laboratory analyses}

At the end of the experiment, five randomly chosen birds per treatment were euthanized using cervical dislocation, according to the American Veterinary Medical Association guidelines [85], and blood samples were collected. Samples were left to coagulate at $4{ }^{\circ} \mathrm{C}$ and centrifuged at $3500 \mathrm{rpm}$ for $15 \mathrm{~min}$ to extract the serum, which was then stored in Eppendorf tubes at $-20{ }^{\circ} \mathrm{C}$ until being analyzed. Samples from different parts of the small intestine were obtained for histological examination.

The serum concentration of total proteins was determined colorimetrically using the biuret method [86]. The serum levels of alkaline phosphatase and IgM were determined using chicken ELISA kits of MyBioSource Co. of CAT.NO. MBS012469, MBS701683, and of ABCAM Co. of CAT. NO. AB157691, respectively. A sandwich enzyme-linked immunosorbent assay (ELISA) kit manufactured by Life Span Biosciences, Inc. of CAT.NO.LS-F9287 was employed to estimate the serum complement 3 levels by following the manufacturer's instructions.

\section{Histological examination of the small intestine}

The tissue samples (approximately $1 \mathrm{~cm}$ ) were obtained from the midpoints of the three segments of the small intestine (duodenum, jejunum, and ileum), gently washed with normal saline to remove any debris, and then fixed in $10 \%$ buffered neutral formalin. The tissue samples were subjected to routine histological processing and embedded in paraffin. Finally, 5-7 micron-thick sections were cut and stained by Harris's hematoxylin and Eosin to elucidate the general structures, Periodic acid Schiff technique for neutral and some acidic mucopolysaccharides, Alcian blue $\mathrm{pH}$ (2.5) for detecting acidic mucopolysaccharides. The methods of processing and staining were adopted following [87]. Image J software (http://Sb.Info.nih.gov/ij/) was applied for performing the measurements, including, Intestinal villi length (from the upper region to the junction between the villus and crypt), villi width, and crypts depth (from the base of the villi to muscularis mucosa) by examination of five different nonoverlapping fields in three separate H\&E-stained sections of different birds in each group on low power field (40x magnification) while the number of goblet cells was on power field (400× magnification). The density of goblet cells was calculated as the number of goblet cells per unit of surface area $\left(\mathrm{mm}^{2}\right)$.

\section{Statistical analysis}

Shapiro-Wilk's test was employed to verify the normality, and Levene's test was exploited to ascertain the homogeneity of variance components between experimental treatments, and the assumption was achieved $(P>0.05)$. Variations were assessed by two-way (ANOVA), and factorial analysis was executed on the factors included in the model, such as feeding regimen, protease supplementation, and their interaction. The differences between the means were compared by the post-hoc Tukey's multiple range tests at $5 \%$ probability. Variation in the data was expressed as pooled SEM. The significance level was set at $P<0.05$.

\section{Abbreviations}

AID\%: Amino acid ileal digestibility coefficient; BW: Body weight; BWG: Body weight gain; Fl: Feed intake; FCR: Feed conversion ratio; RGR: Relative growth rate; PER: Protein efficiency ratio; Ti: Titanium dioxide; AA: Amino acid

\section{Acknowledgements}

The authors would like to acknowledge and thank the Taif University Researchers Supporting Project number (TURSP-2020/134), Taif University, Taif, Saudi Arabia.

\section{Authors' contributions}

SAA: conceptualization, methodology, resources, software, formal analysis, investigation, data curation, visualization, writing-original draft, writing-review and editing. RRB: conceptualization, methodology, re-sources, writing-review and editing. DMA: conceptualization, methodology, writing - review and editing. EMR: conceptualization, methodology, writing—review and editing. FAMH: Conceptualization, methodology, writing - review and editing. TAl: conceptualization, methodology, writing-review and editing. NMAZ: conceptualization, methodology, writing-review and editing. AMAA-E: conceptualization, methodology, writing-review and editing. AEM: conceptualization, methodology, writing-review \& editing. All authors read and approved the final manuscript.

\section{Funding}

This research was funded by the Taif University Researchers Supporting Project number (TURSP-2020/134), Taif University, Taif, Saudi Arabia. 


\section{Availability of data and materials}

The datasets used and analyzed during the current study available from the corresponding author on reasonable request.

\section{Declarations}

\section{Ethics approval and consent to participate}

The experimental protocol was approved by the Ethics of the Institutiona Animal Care and Use Committee of Zagazig University, Egypt (ZUIACUC2020), and all animal experiments were performed following recommendations described in "The Guide for the Care and Use of Laboratory Animals in scientific investigations". All animal experiments were performed following the ARRIVE guidelines.

\section{Consent for publication}

Not applicable.

\section{Competing interests}

The authors declare no competing interests.

\section{Author details}

'Department of Nutrition and Clinical Nutrition, Faculty of Veterinary Medicine, Zagazig University, Zagazig 44511, Egypt. ${ }^{2}$ Department of Histology and Cytology, Faculty of Veterinary Medicine, Zagazig University, Zagazig 44511, Egypt. ${ }^{3}$ Department of Biochemistry, Faculty of Veterinary Medicine, Zagazig University, Zagazig 44511, Egypt. ${ }^{4}$ Animal Wealth Development Department, Faculty of Veterinary Medicine, Zagazig University, Zagazig 44511, Egypt. ${ }^{5}$ Department of Clinical Laboratory Sciences, Turabah University College, Taif University, P.O. Box 11099, Taif 21944, Saudi Arabia. ${ }^{6}$ Department of Economics, Faculty of Commerce, Zagazig University, Zagazig 44511, Egypt. ${ }^{7}$ Department of Pharmacology, Faculty of Veterinary Medicine, Zagazig University, Zagazig 44511, Egypt.

Received: 19 April 2021 Accepted: 18 June 2021

Published online: 25 August 2021

\section{References}

1. Yang Z, Liao SF. Physiological effects of dietary amino acids on gut health and functions of swine. Front Vet Sci. 2019;6:169.

2. Attia YA, Bovera F, Wang J, Al-Harthi MA, Kim WK. Multiple amino acid supplementations to low-protein diets: effect on performance, carcass yield, meat quality and nitrogen excretion of finishing broilers under hot climate conditions. Animals. 2020;10(6):973.

3. Siegert W, Zuber T, Sommerfeld V, Krieg J, Feuerstein D, Kurrle U, Rodehutscord M. Prececal amino acid digestibility and phytate degradation in broiler chickens when using different oilseed meals, phytase and protease supplements in the feed. Poult Sci. 2019;98(11):5700-13.

4. Wilkie DC, Van Kessel AG, White LJ, Laarveld B, Drew MD. Dietary amino acids affect intestinal Clostridium perfringens populations in broiler chickens. Can J Anim Sci. 2005;85(2):185-93.

5. Parr J, Summers J. The effect of minimizing amino acid excesses in broiler diets. Poult Sci. 1991:70(7):1540-9.

6. Moran E Jr, Stilborn H. Effect of glutamic acid on broilers given submarginal crude protein with adequate essential amino acids using feeds high and low in potassium. Poult Sci. 1996;75(1):120-9.

7. Widyaratne G, Drew M. Effects of protein level and digestibility on the growth and carcass characteristics of broiler chickens1. Poult Sci. 2011;90(3): 595-603.

8. Sterling K, Vedenov D, Pesti G, Bakalli R. Economically optimal dietary crude protein and lysine levels for starting broiler chicks. Poult Sci. 2005;84(1):2936.

9. Waldroup P, Jiang Q, Fritts C. Effects of supplementing broiler diets low in crude protein with essential and nonessential amino acids. Int J Poult Sci. 2005;4(6):425-31.

10. Berres J, Vieira S, Dozier lii W, Cortês M, De Barros R, Nogueira E, Kutschenko M. Broiler responses to reduced-protein diets supplemented with valine, isoleucine, glycine, and glutamic acid. J Appl Poult Res. 2010;19(1):68-79.

11. Zulkifli I, Akmal A, Soleimani A, Hossain M, Awad E. Effects of low-protein diets on acute phase proteins and heat shock protein 70 responses, and growth performance in broiler chickens under heat stress condition. Poult Sci. 2018;97(4):1306-14.
12. Sigolo S, Zohrabi Z, Gallo A, Seidavi A, Prandini A. Effect of a low crude protein diet supplemented with different levels of threonine on growth performance, carcass traits, blood parameters, and immune responses of growing broilers. Poult Sci. 2017;96(8):2751-60.

13. Amer SA, Naser MA, Abdel-Wareth AA, Saleh AA, Elsayed SA, Abdel Fattah DM, Metwally AE. Effect of dietary supplementation of alpha-galactosidase on the growth performance, ileal digestibility, intestinal morphology, and biochemical parameters in broiler chickens. BMC Vet Res. 2020;16:1-13.

14. Saeed M, Ayaşan T, Alagawany M, El-Hack M, Abdel-Latif M, Patra A. The role of $B$-mannanase (Hemicell) in improving poultry productivity, health and environment. Braz J Poult Sci. 2019;21(3).

15. Olukosi O, Cowieson A, Adeola O. Age-related influence of a cocktail of xylanase, amylase, and protease or phytase individually or in combination in broilers. Poult Sci. 2007;86(1):77-86.

16. Freitas D, Vieira S, Angel C, Favero A, Maiorka A. Performance and nutrient utilization of broilers fed diets supplemented with a novel monocomponent protease. J Appl Poult Res. 2011;20(3):322-34.

17. Leinonen I, Williams AG. Effects of dietary protease on nitrogen emissions from broiler production: a holistic comparison using Life Cycle Assessment. J Sci Food Agric. 2015;95(15):3041-6.

18. Cowieson A, Abdollahi M, Zaefarian F, Pappenberger G, Ravindran V. The effect of a mono-component exogenous protease and graded concentrations of ascorbic acid on the performance, nutrient digestibility and intestinal architecture of broiler chickens. Anim Feed Sci Technol. 2018; 235:128-37.

19. Malo M, Alam SN, Mostafa G, Zeller S, Johnson P, Mohammad N, Chen K, Moss A, Ramasamy S, Faruqui A. Intestinal alkaline phosphatase preserves the normal homeostasis of gut microbiota. Gut. 2010;59(11):1476-84.

20. Angel C, Saylor W, Vieira S, Ward N. Effects of a monocomponent protease on performance and protein utilization in 7-to 22-day-old broiler chickens. Poult Sci. 2011;90(10):2281-6.

21. Stefanello C, Vieira S, Rios H, Simões C, Sorbara J. Energy and nutrient utilisation of broilers fed soybean meal from two different Brazilian production areas with an exogenous protease. Anim Feed Sci Technol. 2016;221:267-73.

22. Borda-Molina D, Zuber T, Siegert W, Camarinha-Silva A, Feuerstein D, Rodehutscord M. Effects of protease and phytase supplements on small intestinal microbiota and amino acid digestibility in broiler chickens. Poult Sci. 2019;98(7):2906-18.

23. Walk C, Pirgozliev V, Juntunen $K$, Paloheimo M, Ledoux D. Evaluation of novel protease enzymes on growth performance and apparent ileal digestibility of amino acids in poultry: enzyme screening. Poult Sci. 2018;97(6):2123-38.

24. Boguhn J, Broz J, Rodehutscord M. Amino acid digestibility of soybean meal and DDGS without and with supplementation of a protease in turkeys. In: Proc 18th Eur Symp Poult Nutr, Ceșme/lzmir, Turkey. 2011;2011:542-44.

25. Kaczmarek S, Rogiewicz A, Mogielnicka M, Rutkowski A, Jones R, Slominski B. The effect of protease, amylase, and nonstarch polysaccharide-degrading enzyme supplementation on nutrient utilization and growth performance of broiler chickens fed corn-soybean meal-based diets. Poult Sci. 2014;93(7):1745-53.

26. Erdaw MM, Wu S, lji PA. Growth and physiological responses of broiler chickens to diets containing raw, full-fat soybean and supplemented with a high-impact microbial protease. Asian Australas J Anim Sci. 2017;30(9):1303.

27. Manangi M, Sands J, Coon C. Effect of phytase on ileal amino acid digestibility, nitrogen retention and AMEn for broilers fed diets containing low and high phytate phosphorus. Int J Poult Sci. 2009;8:929-38.

28. Woyengo T, Beltranena E, Zijlstra R. Nonruminant nutrition symposium: controlling feed cost by including alternative ingredients into pig diets: a review. J Anim Sci. 2014;92(4):1293-305.

29. Pereira L, Adeola O. Energy and phosphorus values of sunflower meal and rice bran for broiler chickens using the regression method. Poult Sci. 2016; 95(9):2081-9.

30. Villamide M, San Juan L. Effect of chemical composition of sunflower seed meal on its true metabolizable energy and amino acid digestibility. Poult Sci. 1998;77(12):1884-92.

31. Attia Y, Al-Harthi M, El-Deek A. Nutritive value of undehulled sunflower meal as affected by multienzyme supplementation to broiler diets. Archiv Fur Geflugelkunde. 2003;67(3):97-106

32. Council NR. Nutrient requirements of swine. Washington, DC: National Academies Press; 2012

33. Lević JD, Sredanović SA, Đuragić OM. Sunflower meal protein as a feed for broilers. Acta Period Technol. 2005;36:3-10. 
34. Cozannet P, Lessire M, Métayer J, Gady C, Primot $Y$, Geraert P, Tutour L, Skiba F, Noblet J. Nutritive value of wheat and maize distillers dried grains with solubles in poultry. INRA Prod Anim. 2010;23(5):405-14.

35. Salim H, Kruk Z, Lee B. Nutritive value of corn distillers dried grains with solubles as an ingredient of poultry diets: a review. Worlds Poult Sci J. 2010; 66(3):411-32.

36. Kamran Z, Mirza MA, Mahmood S. Effect of decreasing dietary protein levels with optimum amino acids profile on the performance of broilers. Pak Vet J. 2004: Citeseer; 2004

37. Cardinal KM, Moraes MLd, Andretta I, Schirmann GD, Belote BL, Barrios MA Santin E, Ribeiro AML. Growth performance and intestinal health of broilers fed a standard or low-protein diet with the addition of a protease. Rev Bras Zootecnia. 2019:48:e20180232

38. Lourenco JM, Nunn SC, Lee E, Dove CR, Callaway TR, Azain MJ. Effect of supplemental protease on growth performance and excreta microbiome of broiler chicks. Microorganisms. 2020;8(4):475

39. Toghyani M, Wu S, Pérez-Maldonado R, lji P, Swick RA. Performance, nutrient utilization, and energy partitioning in broiler chickens offered high canola meal diets supplemented with multicomponent carbohydrase and monocomponent protease. Poult Sci. 2017;96(11):3960-72.

40. Dalólio FS, Albino LFT, Rostagno HS, Silva DLd, Xavier Júnior MdL, Oliveira VDd. Metabolizable energy and digestible amino acids of full-fat soybean without or with protease supplementation in diets for broilers. Ciência e Agrotecnol. 2016;40(5):565-76.

41. Mahmood T, Mirza M, Nawaz H, Shahid M. Exogenous protease supplementation of poultry by-product meal-based diets for broilers: effects on growth, carcass characteristics and nutrient digestibility. J Anim Physiol Anim Nutr. 2018;102(1):e233-41.

42. Selle PH, Truong HH, McQuade LR, Moss AF, Liu SY. Reducing agent and exogenous protease additions, individually and in combination, to wheat-and sorghum-based diets interactively influence parameters of nutrient utilisation and digestive dynamics in broiler chickens. Anim Nutr. 2016;2(4):303-11.

43. Kamran Z, Sarwar M, Nisa M, Nadeem M, Mahmood S, Babar M, Ahmed S. Effect of low-protein diets having constant energy-to-protein ratio on performance and carcass characteristics of broiler chickens from one to thirty-five days of age. Poult Sci. 2008;87(3):468-74.

44. Kamran Z, Sarwar M, Nisa M, Nadeem MA, Mahmood S. Effect of low levels of dietary crude protein with constant metabolizable energy on nitrogen excretion, litter composition and blood parameters of broilers. Int J Agric Biol. 2010;12:401-5.

45. Law FL, Zulkifli I, Soleimani AF, Liang JB, Awad EA. The effects of lowprotein diets and protease supplementation on broiler chickens in a hot and humid tropical environment. Asian Australas J Anim Sci. 2018;31(8): 1291.

46. Mahmood T, Mirza M, Nawaz H, Shahid M. Effect of different exogenous proteases on growth performance, nutrient digestibility, and carcass response in broiler chickens fed poultry by-product meal-based diets. Livest Sci. 2017;200:71-5

47. Cowieson A, Ravindran V. Effect of exogenous enzymes in maize-based diets varying in nutrient density for young broilers: growth performance and digestibility of energy, minerals and amino acids. Br Poult Sci. 2008; 49(1):37-44

48. Hussain M, Mirza M, Nawaz H, Asghar M, Ahmed G. Effect of exogenous protease, mannanase, and xylanase supplementation in corn and high protein corn DDGS based diets on growth performance, intestinal morphology and nutrient digestibility in broiler chickens. Braz J Poult Sci. 2019;21(4).

49. Youssef IM, Westfahl C, Sünder A, Liebert F, Kamphues J. Evaluation of dried distillers' grains with solubles (DDGS) as a protein source for broilers. Arch Anim Nutr. 2008;62(5):404-14

50. Loar R II, Moritz J, Donaldson J, Corzo A. Effects of feeding distillers dried grains with solubles to broilers from 0 to 28 days posthatch on broiler performance, feed manufacturing efficiency, and selected intestinal characteristics. Poult Sci. 2010;89(10):2242-50.

51. Zhang $Y$, Shan A, Jiang W, Bi C, Li Z. The effect of vitamin E on growth performance and meat quality in broilers given diets containing distillers' dried grain with solubles (DDGS). Br Poult Sci. 2013;54(1):138-43.

52. Campasino A, Williams M, Latham R, Bailey C, Brown B, Lee J. Effects of increasing dried distillers' grains with solubles and non-starch polysaccharide degrading enzyme inclusion on growth performance and energy digestibility in broilers. J Appl Poult Res. 2015;24(2):135-44.
53. Olukosi O, Beeson L, Englyst K, Romero L. Effects of exogenous proteases without or with carbohydrases on nutrient digestibility and disappearance of non-starch polysaccharides in broiler chickens. Poult Sci. 2015;94(11): 2662-9.

54. Saleh AA, Dawood MM, Badawi NA, Ebeid TA, Amber KA, Azzam MM. Effect of supplemental serine-protease from Bacillus licheniformis on growth performance and physiological change of broiler chickens. J Appl Anim Res. 2020;48(1):86-92.

55. Barekatain MR, Antipatis C, Rodgers N, Walkden-Brown SW, lji P, Choct M. Evaluation of high dietary inclusion of distillers dried grains with solubles and supplementation of protease and xylanase in the diets of broiler chickens under necrotic enteritis challenge. Poult Sci. 2013;92(6):1579-94.

56. Ndazigaruye G, Kim D-H, Kang C-W, Kang K-R, Joo Y-J, Lee S-R, Lee K-W. Effects of low-protein diets and exogenous protease on growth performance, carcass traits, intestinal morphology, cecal volatile fatty acids and serum parameters in broilers. Animals. 2019;9(5):226.

57. Swatson HK, Gous R, lji PA, Zarrinkalam R. Effect of dietary protein level, amino acid balance and feeding level on growth, gastrointestinal tract, and mucosal structure of the small intestine in broiler chickens. Anim Res. 2002; 51(6):501-15.

58. Wang J, Peng K. Developmental morphology of the small intestine of African ostrich chicks. Poult Sci. 2008;87(12):2629-35.

59. Franco J, Murakami A, Natali M, Garcia E, Furlan A. Influence of delayed placement and dietary lysine levels on small intestine morphometrics and performance of broilers. Brazilian J Poult Sci. 2006;8(4):233-41.

60. Amer SA, A-Nasser A, Al-Khalaifah HS, AlSadek DM, Roushdy EM, Sherief WR, Farag MF, Altohamy DE, Abdel-Wareth AA, Metwally AE. Effect of dietary medium-chain a-monoglycerides on the growth performance, intestinal histomorphology, amino acid digestibility, and broiler chickens' blood biochemical parameters. Animals. 2021;11(1):57.

61. Incharoen T, Yamauchi K-E, Erikawa T, Gotoh H. Histology of intestinal villi and epithelial cells in chickens fed low-crude protein or low-crude fat diets. Ital J Anim Sci. 2010;9(4):e82.

62. Amer SA, Mohamed WA, Gharib HS, Al-Gabri NA, Gouda A, Elabbasy MT, Abd El-Rahman Gl, Omar AE. Changes in the growth, ileal digestibility, intestinal histology, behavior, fatty acid composition of the breast muscles, and blood biochemical parameters of broiler chickens by dietary inclusion of safflower oil and vitamin C. BMC Vet Res. 2021;17(1):1-18.

63. Omar AE, Al-Khalaifah HS, Mohamed WA, Gharib HS, Osman A, Al-Gabri NA, Amer SA. Effects of phenolic-rich onion (Allium cepa L.) extract on the growth performance, behavior, intestinal histology, amino acid digestibility, antioxidant activity, and the immune status of broiler chickens. Front Vet Sci. 2020;7:728.

64. Yamauchi K-e. Review on chicken intestinal villus histological alterations related with intestinal function. J Poult Sci. 2002;39(4):229-42.

65. Lensing M, Van Der Klis J, Le Bellego L, Rovers M. The threonine requirement of broiler chickens during subclinical intestinal infection. In: Proceedings of the 16th European Nutrition Symposium: 2007;2007:343-6.

66. Laudadio V, Passantino L, Perillo A, Lopresti G, Passantino A, Khan R, Tufarelli $V$. Productive performance and histological features of intestinal mucosa of broiler chickens fed different dietary protein levels. Poult Sci. 2012;91(1):26570.

67. Buwjoom T, Yamauchi K, Erikawa T, Goto H. Histological intestinal alterations in chickens fed low protein diet. J Anim Physiol Anim Nutr. 2010;94(3):354-61.

68. Barekatain R, Nattrass G, Tilbrook A, Chousalkar K, Gilani S. Reduced protein diet and amino acid concentration alter intestinal barrier function and performance of broiler chickens with or without synthetic glucocorticoid. Poult Sci. 2019:98(9):3662-75.

69. Moghaddam HN, Salari S, Arshami J, Golian A, Maleki M. Evaluation of the nutritional value of sunflower meal and its effect on performance, digestive enzyme activity, organ weight, and histological alterations of the intestinal villi of broiler chickens. J Appl Poult Res. 2012;21(2):293-304.

70. Perez Mendoza VG, Effects of distillers dried grains with solubles and dietary fiber on the intestinal health of young pigs and chicks. University of Illinois at Urbana-Champaign; 2011.

71. Perez V, Jacobs C, Barnes J, Jenkins M, Kuhlenschmidt M, Fahey G Jr, Parsons C, Pettigrew J. Effect of corn distillers dried grains with solubles and Eimeria acervulina infection on growth performance and the intestinal microbiota of young chicks. Poult Sci. 2011;90(5):958-64.

72. Whitney M, Shurson G, Guedes R. Effect of including distillers dried grains with solubles in the diet, with or without antimicrobial regimen, on the 
ability of growing pigs to resist a Lawsonia intracellularis challenge. J Anim Sci. 2006;84(7):1870-9.

73. Weber T, Ziemer C, Kerr B. Effects of adding fibrous feedstuffs to the diet of young pigs on growth performance, intestinal cytokines, and circulating acute-phase proteins. J Anim Sci. 2008;86(4):871-81.

74. Additives EPo, Feed PoSuiA. Scientific Opinion on the safety and efficacy of Cibenza ${ }^{\oplus}$ EP150 (a preparation of Bacillus licheniformis (ATCC 53757) and its protease (EC 3.4. 21.19)) as a feed additive for chickens for fattening, chickens reared for laying and minor avian species for fattening and to point of lay and ornamental birds. EFSA J. 2015;13(3):4055.

75. AVIAGEN R. Ross Broiler Management Manual, 2009. http://ptaviagen.com/a ssets/Tech_Center/Ross_Broiler/Ross_Broiler_Manual_. 2014;9:350-64.

76. Brody S. Bioenergetics and growth; with special reference to the efficiency complex in domestic animals. 1945.

77. McDonald P, Edwards R, Greenhalgh J. Animal nutrition: by P. McDonald, RA Edwards and JFD Greenhalgh. Edinburgh: Oliver \& Boyd; 1973.

78. Li X, Ni Gusti Ayu M, Zhang D, Bryden W. Apparent ileal amino acid digestibility of Australian sorghum. 2006.

79. Siriwan P, Bryden W, Mollah Y, Annison E. Measurement of endogenous amino acid losses in poultry. Br Poult Sci. 1993;34(5):939-49.

80. Ravindran G, Bryden W. Tryptophan determination in proteins and feedstuffs by ion exchange chromatography. Food Chem. 2005;89(2):30914.

81. Fenton T, Fenton M. An improved procedure for the determination of chromic oxide in feed and feces. Can J Anim Sci. 1979;59(3):631-4.

82. El-Telbany M, Atallah S. Some culture factors affecting the productive and economic efficiency of Mugil capito nursing in earthen pond system 9th scientific Cingrees. Fac Vet Med Assiut Univ. 2000;46:19-20.

83. Dunning R, Daniels H. Hybrid striped bass production in ponds: enterprise budget. Stoneville: Southern Regional Aquaculture Center; 2001.

84. North M, Bell D. Breeder management. Connecticut: Commercial Chicken Production Manual The Avi Publishing Company Inc Westport; 1984. p. 240-321.

85. Association AVM. AVMA guidelines for the euthanasia of animals: 2013 edition. Schaumburg: American Veterinary Medical Association; 2013.

86. Henry J. Clinical diagnosis and measurement by laboratory methods. In: Todd-Sanford-Davidsohn. Philadephia: WB Saunders; 1974

87. Layton C, Bancroft JD. Bancroft's theory and practice of histological techniques. Amsterdam: Elsevier; 2019.

\section{Publisher's Note}

Springer Nature remains neutral with regard to jurisdictional claims in published maps and institutional affiliations.

Ready to submit your research? Choose BMC and benefit from:

- fast, convenient online submission

- thorough peer review by experienced researchers in your field

- rapid publication on acceptance

- support for research data, including large and complex data types

- gold Open Access which fosters wider collaboration and increased citations

- maximum visibility for your research: over $100 \mathrm{M}$ website views per year

At $\mathrm{BMC}$, research is always in progress.

Learn more biomedcentral.com/submissions 